Available online at GSC Online Press Directory

GSC Biological and Pharmaceutical Sciences

e-ISSN: 2581-3250, CODEN (USA): GBPSC2

Journal homepage: https://www.gsconlinepress.com/journals/gscbps

(RESEARCH ARTICLE)

\title{
Resistance mechanisms of late leaf spot and rosette diseases in drought tolerant groundnut genotypes
}

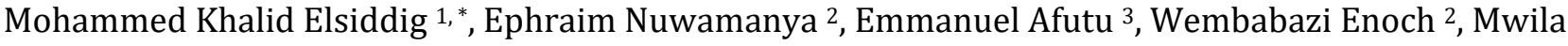 \\ Natasha ${ }^{1}$, Siddig Eisa Idris ${ }^{4}$ and Rubaihayo Patrick R. ${ }^{1}$ \\ ${ }^{1}$ College of Agriculture and Environmental Sciences, Makerere University, P. O. Box 7062, Kampala, Uganda. \\ ${ }^{2}$ National Crops Resources Research Institute (NaCRRI), P. O. Box 7084, Kampala, Uganda. \\ ${ }^{3}$ Department of Crop Science, School of Agriculture, College of Agriculture and Natural Sciences, University of Cape Coast, \\ Cape Coast, Ghana. \\ ${ }^{4}$ University of Gezira Faculty of Agricultural Sciences Department of Crop science P.O. Box: 20, Sudan.
}

Publication history: Received on 14 June 2019; revised on 04 July 2019; accepted on 09 July 2019

Article DOI: https://doi.org/10.30574/gscbps.2019.8.1.0105

\begin{abstract}
Groundnut has been identified as less susceptible to drought which produces moderate yield under drought conditions. Also, drought can enhance effects of late leaf spot and groundnut rosette diseases. However, to reduce rate of the damage by these constraints, plants produce various defensive metabolites. This investigation was undertaken to study how drought tolerant groundnut genotypes respond under late leaf spot and rosette diseases. Eleven drought tolerant genotypes, comprising 4 resistance to both diseases, 4 resistant to leaf spot and 3 resistant to rosette disease were selected for the study. The experiments were conducted in the screen house at two locations (Namulonge and Kabanyolo) and arranged in a complete randomized design. Diseases and drought were artificially imposed two weeks after germination. Data collected included aphid counts, chlorophyll, phenolic and tannin content. The analysis of variance showed significant differences $(\mathrm{P}<0.001)$ in most of the studied traits for the two sites, genotypes and the interaction. Rosette resistant genotypes recorded the lowest aphid counts and the highest tannin contents. The lowest total chlorophyll was shown by late leaf spot susceptible genotypes. Tannin content was negatively correlated with chlorophylls and aphid counts whiles total phenolic content was negatively correlated with aphid counts but was positively correlated with chlorophyll. The negative correlation between the measured metabolites and chlorophyll with aphid population, rosette and leaf spot disease indicated that an increase in these biochemical content led to a decrease in disease occurrence and therefore, increasing metabolites could contribute to the bio-protection of host plants against these diseases.
\end{abstract}

Keywords: Arachis hypogaea; Biochemical; Cercospora; Aphids; Moisture stress

\section{Introduction}

Groundnut (Arachis hypogaea L.) is one of the five most important oilseed crops in the world [1]. The crop plays an important role in the agricultural economy of semi-arid tropical countries. It is an important component of food in East Africa especially, Uganda, and has the highest return for labor input compared to other food crops [2]. Groundnut contributes to food security, income generation and the overall economic growth for agriculture-based industries [3] and contains around 40-54\% oil which is a rich source of vitamin A, B and E. Groundnut crop is environmentally friendly and adapted to a wide range of conditions and is therefore, popular with African farmers because of its ability to yield on poor soils. The crop has been identified as drought tolerant [4] and given its drought tolerance, it has the

\footnotetext{
${ }^{*}$ Corresponding author

E-mail address: khalidelsiddig24@gmail.com
}

Copyright (C) 2019 Author(s) retain the copyright of this article. This article is published under the terms of the Creative Commons Attribution Liscense 4.0 
potential to provide food security in the dry areas of Africa. In addition, Doku, [5] noted that it was an easy crop to cultivate and does not make much demand on the soil.

Different biotic and abiotic stresses affect groundnut production and quality. Among them are a variety of diseases which hamper groundnut production [6] including viral, bacterial, fungal and/or nematode based diseases [7] Among the soil borne fungal pathogens are those causing the late leaf spot (LLS) disease which is more common and more destructive to groundnut. LLS caused by Cercospora personatum is present every year on groundnut in sub Saharan Africa [8] and can decrease seed production by over $50 \%$, if no fungicides are applied for control [9]. In addition to late leaf spot, groundnut rosette disease (GRD) is also widespread and devastating viral disease of groundnut in all the major groundnut growing regions in sub-Saharan Africa (SSA) including Uganda [10]. The yield of groundnut has been reported to be low in Eastern Africa, more especially, Uganda [11] due to attack by GRD [12]. Yield loss from GRD in SSA has been reported to be up to $100 \%$ depending on growth stage and groundnut variety [13]. The disease is transmitted by the aphid (Aphis craccivora Koch) and as a result, A. craccivora is highly associated to yield losses [8].

Drought is a major challenge in the Eastern and North Eastern Regions of Uganda where groundnut is grown and cultivation of the crop faces conditions of water stress. Functional response of plants to drought have been linked to their tolerance mechanisms [14] such as pigment content and stability and relative water content [15]. Drought tolerant plants maintain green shoot system which thus increase the production of resistance metabolites under conditions of water stress [16] and therefore, protects the plant from further damage. Several metabolites have been reported as associated to LLS and GRD resistance in groundnut. Phenols usually play an important role in groundnut resistance to fungal diseases [17]. Phenols were found to increase in both resistant and susceptible varieties to LLS during infection [18], but, the magnitude of increase in content of phenols due to infection in resistant genotypes is not well understood. There is therefore, limited information on physiological and biochemical mechanisms conferring resistance to diseases and hence, this investigation was undertaken to study the response of drought tolerant groundnut genotypes to metabolites under infection of late leaf spot and rosette diseases.

\section{Material and methods}

\subsection{Planting materials}

Eleven groundnut genotypes with different reactions (resistance and susceptibility) to late leaf spot (LLS) and groundnut rosette disease (GRD) and drought tolerance (Table 1) were used to study the resistance mechanisms to the diseases. Four genotypes were resistant to LLS+GRD, four genotypes were resistant to LLS and three genotypes were resistant to GRD.

Table 1 Descriptions of materials used in the study

\begin{tabular}{lllll}
\hline No. & Genotype & LLS attribute & GRD attribute & Treatment \\
\hline 1 & Abutalata & resistant & resistant & LLS, GRD and D \\
2 & SGV ER 10003 & resistant & resistant & LLS, GRD and D \\
3 & C1 & resistant & resistant & LLS, GRD and D \\
4 & C2 & resistant & resistant & LLS, GRD and D \\
5 & SGV ER 10004 & susceptible & resistant & GRD and D \\
6 & SGV ER 10009 & susceptible & resistant & GRD and D \\
7 & SGV 0074 & susceptible & resistant & GRD and D \\
8 & C11 & resistant & susceptible & LLS and D \\
9 & C12 & resistant & susceptible & LLS and D \\
10 & SGV AW. 0803 & resistant & susceptible & LLS and D \\
11 & SGV AW. 0804 & resistant & susceptible & LLS and D \\
\hline
\end{tabular}

Source: National Semi Arid Resources Research Institute (NaSARRI). LLS: Late leaf spot, GRD: Groundnut rosette disease, D: Drought. Genotypes were treated with LLS and GRD according to their resistance capacity 


\subsection{Experimental sites}

The experiments were carried out in the screen house between $11^{\text {th }}$ January and $10^{\text {th }}$ May 2017, at the National Crops Resources Research Institute (NaCRRI) which lies at $0^{\circ} 32^{\prime \prime} \mathrm{N} 32^{\circ} 37^{\prime \prime} \mathrm{E}$, and at an altitude of $1200 \mathrm{~m}$ above sea level (m. a. s. l) and Makerere University Agricultural Research Institute Kabanyolo (MUARIK) which lies at $0^{\circ} 28^{\prime} \mathrm{N}$ and $32^{\circ} 37^{\prime} \mathrm{E} ; 1200$ m. a. s. 1 [19].

\subsection{Experimental design}

The experiments were arranged using complete randomized design (CRD) in two replications.

\subsection{Infection with LLS}

Leaf debris infected with Cercospora personata were collected from the field into cloth bags and stored in farm shed for use in the experiments [20]. Spores were prepared and sprayed uniformly 15 days after planting (DAP) in the evening following the method by Ibrahim, [21].

\subsection{Infection with GRD}

Greenhouse infestation with virulent aphids was done following the method by Kayondo, et al [22]. Aphids obtained from groundnut plants infected with GRD from the field as evidenced by green and chlorotic rosette symptoms were transferred onto disease free susceptible plants (JL 24 and Acholi white) two weeks after germination. Infected genotypes were kept in cages for maintenance of large stocks of virulent aphids to be used during the experiment. Two weeks after germination of the experimental plants, infector rows (Acholi-white and JL-24) were placed between each two rows of the experimental materials, aphids were free to move to find suitable plant hosts. The aphid count was recorded four times every two weeks interval.

\subsection{Drought stress}

Two watering regimes, $80 \%$ and $60 \%$ of field capacity (FC) denoted as $\mathrm{T} 1$ and $\mathrm{T} 2$, respectively, [23] were used to evaluate plant performance in the absence of soil moisture stress at T1 (control), whereas the T2 watering regime simulated soil moisture stress. The drought stress initiated fifteen days after planting and maintained at the required experimental soil moisture contents at $80 \%$ and $60 \%$ of FC through supplemental watering, based on the moisture meter readings (Soil moisture meter Lutron Pms714 Dpstar, Bangladesh) [24].

\subsection{Biochemical analysis of late leaf spot resistance mechanisms}

\subsubsection{Estimation of chlorophyll}

Chlorophyll estimation of healthy and inoculated genotypes was done at 30 days after inoculation [25]. The third leaf from the apex of groundnut plants was chosen in all genotypes and 20 such leaves were randomly collected per pot for chlorophyll estimation [26]. The following formulae were used;

Total chlorophyll: $(20.2 \times$ OD at $645 \mathrm{~nm})+(8.02 \times$ OD at $663 \mathrm{~nm}) \mathrm{df}$,

Chlorophyll 'A': (12.7 x OD at $663 \mathrm{~nm})-(2.69$ x OD at $645 \mathrm{~nm}) \mathrm{df}$,

Chlorophyll 'B': (22.9 x OD at $645 \mathrm{~nm})-(4.68 \mathrm{x}$ OD at $663 \mathrm{~nm}) \mathrm{df}$.

Where, $\mathrm{OD}=$ optical Density; $\mathrm{df}=$ dilution factor, was used for the estimation of total chlorophyll, chlorophyll 'A' and chlorophyll 'B' and the results were expressed as $\mathrm{mg}$ of chlorophyll/g of fresh weight.

\subsubsection{Estimation of total phenolic contents}

Total phenol content was estimated using folin-ciocalteau reagent. Eighty percent ethanol was employed for efficient extraction [27]. 1 gram of plant material (fresh) was ground in $5 \mathrm{ml}$ portion of $80 \%$ ethanol and centrifuged at 10,000 rpm for 20 minutes. $0.1 \mathrm{ml}$ of centrifuged plant material was evaporated on a water bath. $6 \mathrm{ml}$ of water was added to it and shaken well followed by addition of $0.5 \mathrm{ml}$ of folin-ciocalteau reagent [28]. After 5 minutes, $2 \mathrm{ml} 20 \%$ Sodium Carbonate was added to each tube and mixed thoroughly and incubated for 30 minutes at $25^{\circ} \mathrm{C}$. The absorbance was measured at $650 \mathrm{~nm}$ (Milton Roy) in mg per $100 \mathrm{~g}$ of tissue. The phenol content in the leaf extract was determined using catechol (phenol) as standard with a standard graph being obtained based on different concentrations of catechol [28]. 


\subsection{Assessment of rosette disease mechanism of resistance}

\subsubsection{Extraction and purification of the condensed tannin}

Tannins were extracted following the method by Mwila et al. [29]. A $100 \mathrm{mg}$ leaf sample was placed into a $2 \mathrm{ml}$ tube, where $0.5 \mathrm{ml}$ of $5 \%$ ascorbic acetone solution was added to dissolve leaf sample and the setup placed on an orbital shaker for 20 minutes. After this, $0.5 \mathrm{ml}$ of petroleum ether containing 1\% acetic acid, was added to remove pigments. $0.3 \mathrm{ml}$ of distilled water was added and centrifuged for 10 minutes at 1,000 rpm. This was followed by placing the solution in a $50 \mathrm{ml}$ conical flask and adding $2.4 \mathrm{ml}$ of $5 \%$ hydrochloric acid (HCL)-butanol solution. The solution in the flask was run through a $240 \mathrm{~mm}$ filter paper (WHA1001240- ALDRICH, Missouri, USA). After this, $0.5 \mathrm{ml}$ of the filtrate was made up to $1 \mathrm{ml}$ with distilled water and $0.5 \mathrm{ml}$ of folin ciocalteau reagent was added; followed with $2.5 \mathrm{ml}$ of $20 \%$ sodium carbonate solution and mixed [30]. A total of $0.1 \mathrm{ml}$ of the mixture was then incubated at $80{ }^{\circ} \mathrm{C}$ for 1 hour and 20 minutes and the samples were cooled to $24^{\circ} \mathrm{C}$ and spectrophotometric readings were taken at $550 \mathrm{~nm}$ [29].

\subsection{Data analysis}

All data were subjected to analysis of variance (ANOVA) using the GenStat computer package (14th edition, $\mathrm{PC} /$ windows 7). The mean, mean sum of squares, coefficients of variations and correlations were calculated from the aphid count, chlorophyll A, B and total chlorophyll, total phenolic content and tannins. General analyses of variance were used to examine the mean variations among the various genotypes [31]. Where the ANOVA showed significant differences, the means were separated using least significant difference (LSD) Tests at 5\% probability level.

\section{Results and discussion}

\subsection{Analysis of variance of aphids counts}

The results of analysis of variance of aphids counts (insect plant ${ }^{-1}$ ) are presented in Table 2 .

Table 2 Means of sum of squares of Aphid counts on resistant and susceptible plants to LLS, GRD and drought tolerance

\begin{tabular}{llllll}
\hline SoV & DF & $\begin{array}{l}\text { Aphids } \\
\text { count 1 }\end{array}$ & $\begin{array}{l}\text { Aphids } \\
\text { count } 2\end{array}$ & $\begin{array}{l}\text { Aphids count } \\
\mathbf{3}\end{array}$ & $\begin{array}{l}\text { Aphids } \\
\text { count 4 }\end{array}$ \\
\hline Rep & 1 & 497 & 1838 & 282.5 & 389 \\
Genotype (G) & 8 & $6319^{* * *}$ & $35264^{* * *}$ & $15399^{* * *}$ & $16414^{* * *}$ \\
Location (L) & 1 & $61328^{* * *}$ & 568 & $292208.9^{* * *}$ & $575380^{* * *}$ \\
Treatment (T) & 3 & $25529^{* * *}$ & $40973^{* * *}$ & $8765.9^{* * *}$ & $12321^{* *}$ \\
Gx L & 8 & $7326^{* * *}$ & $11585^{* *}$ & $10260.3^{* * *}$ & $15897^{* * *}$ \\
Gx T & 17 & $2883^{*}$ & 5339 & $3312.1^{* * *}$ & $5695^{*}$ \\
L x T & 3 & 1317 & $116371^{* * *}$ & $17399.9^{* * *}$ & $12288^{* *}$ \\
G x Lx T & 17 & 2305 & $8500^{*}$ & $3925.1^{* * *}$ & $5743^{*}$ \\
Residual & 57 & 1509 & 4733 & 871 & 3229 \\
Total & 115 & 3645 & 11628 & 6289.6 & 10657 \\
CV\% & & 64.56 & 55.77 & 33.2 & 74.64 \\
\hline
\end{tabular}

LLS: Late leaf spot disease, GRD: Groundnut rosette disease, SOV: Source of variance, DF: Degree of freedom, ${ }^{* * *},{ }^{* *},{ }^{*}$ Significant at P<0.001; 0.01 and 0.05 , respectively

Aphids counts showed highly significant differences $(\mathrm{P}<0.001)$ for the following, namely; for genotypes across the four counts, genotype-by-location interactions at the first, third and fourth counts, location-by-treatment interaction at second and third counts and genotype-by-location-by-treatment interaction at third count. This indicated that genotypes with resistance to aphids existed in the genetic materials across the locations and treatments. 
Means of aphid counts at MUARIK and NaCRRI are presented in Fig 1.
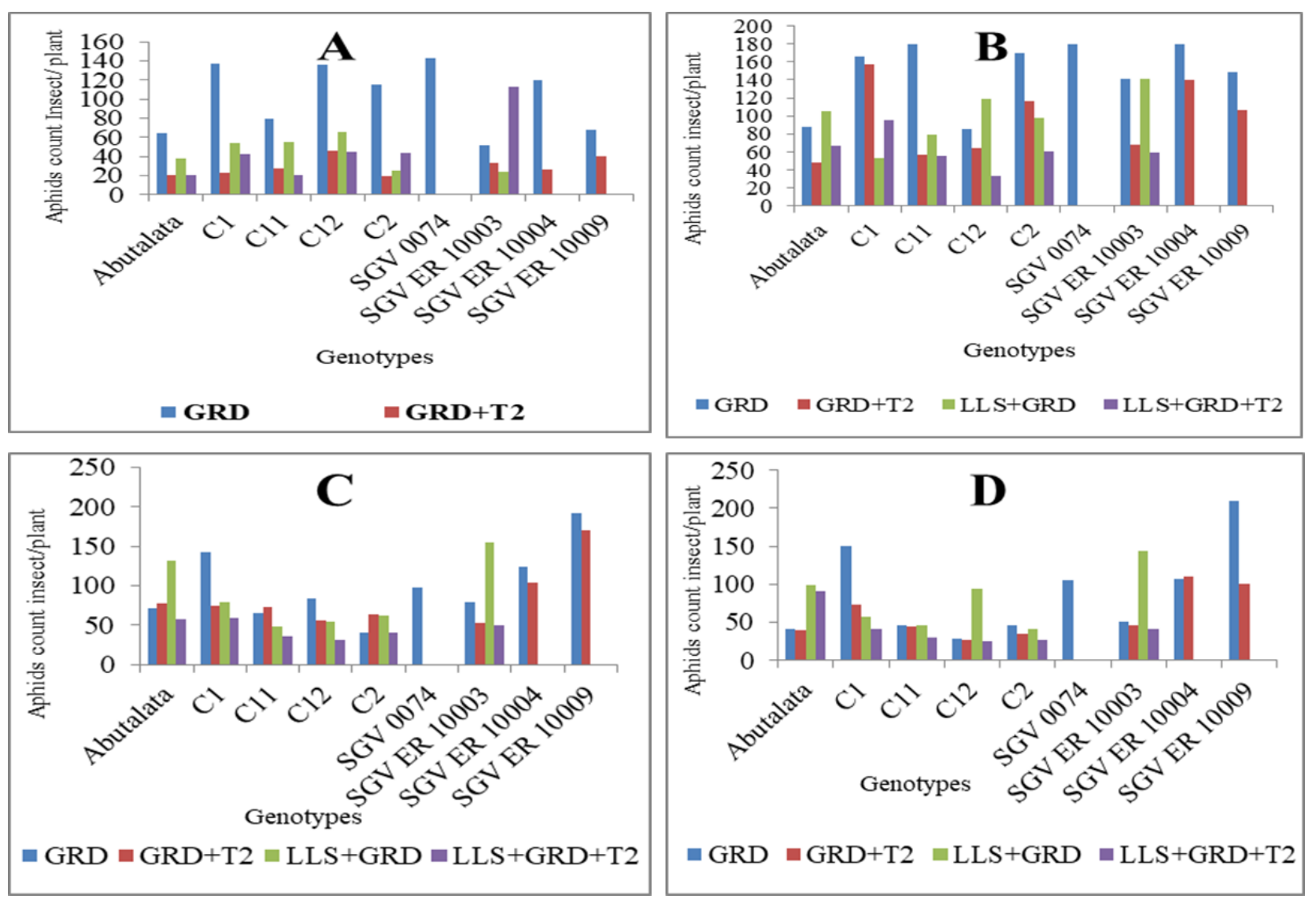

Figure 1 Average aphids count of 9 groundnut genotypes across 4 different stresses at MUARIK and NaCRRI. A, B, C and $\mathrm{D}$ represent Average aphids population at $1^{\text {st }}, 2^{\text {nd }}, 3^{\text {rd }}$ and $4^{\text {th }}$ counts, respectively. The counts were recorded at two weeks intervals.

The highest number of aphids recorded were 335 and 405 for genotype SGV ER 10009 at MUARIK under groundnut rosette disease (GRD) treatment at third and fourth counts, respectively. This high number of aphids on resistant genotype indicated that the resistance to GRD did not affect aphids infestation, instead, the aphids were attracted towards the green flourishing available option compared to susceptible damaged genotypes by the feeding of aphids [32]. When subjected to high virulent pathogen carrying aphid pressure, the resistant genotypes recorded some GRD infection, however, they still performed better compared to the susceptible genotypes. Similar findings were reported by kayondo et al, [22]. The high number of aphids on resistant genotypes was attributed to the plant's inability to produce sufficient quantity of tannins substances under high aphids pressure [33].

The lowest aphids counts, 3, 3.5, and 6 recorded by Abutalata, C12 and SGV ER 10003 at count 4 under LLS+GRD, LLS+GRD+T2 and GRD+T2, respectively, indicated that the movement of aphids populations among the genotypes to seek for the suitable host with low tannin was responsible for aphids movement away from the plants [34].

\subsection{Analysis of variance of total phenolic and tannin contents $(\mathrm{g} / \mathrm{ml})$}

The results of analysis of variance of total phenolic contents $(\mathrm{g} / \mathrm{ml})$ and tannin contents $(\mathrm{g} / \mathrm{ml})$ are presented in Table 3. 
Table 3 Means of sum of squares of phenolic and tannins contents of resistant and susceptible to LLS, GRD and drought tolerant groundnut genotypes

\begin{tabular}{llll}
\hline SOV & DF & Phenolics & Tannin \\
\hline Rep & 1 & 0.0002 & 0.009406 \\
Genotype (G) & 8 & $0.016611^{* * *}$ & 0.011711 \\
Location (L) & 1 & $1.906211^{* * *}$ & 0.010752 \\
Treatment (T) & 8 & $0.03272^{* * *}$ & $0.101422^{* * *}$ \\
G x L & 8 & $0.017398^{* * *}$ & $0.025973^{* * *}$ \\
Gx T & 41 & $0.002301^{*}$ & $0.012354^{* *}$ \\
L x T & 8 & $0.032342^{* * *}$ & $0.025804^{* * *}$ \\
Gx L x T & 41 & $0.002454^{*}$ & 0.007913 \\
Residual & 115 & 0.0016 & 0.007001 \\
Total & 231 & 0.012 & 0.012437 \\
CV\% & & 38.62 & 56.01
\end{tabular}

LLS: Late leaf spot disease, GRD: Groundnut rosette disease, SOV: Source of variance, DF: degree of freedom, ${ }^{* * *},{ }^{* *},{ }^{*}$ Significant at $\mathrm{P}<0.001 ; 0.01$ and 0.05 , respectively.

Tannins showed highly significant differences $(\mathrm{P}<0.001)$ for genotype-by-location and location-by-water stress interactions indicating the effect of both locations and water stress on tannins content among the genotypes, which suggests increase in tannins amongst the genotypes under stress [35]. However, Alpha [36] reported significant difference of tannin levels among genotypes with high tannins being recorded in the resistant genotypes.

Phenolics content showed highly significant differences $(\mathrm{P}<0.001)$ among genotypes, genotype-by-location, locationby-water stress interactions and significant differences $(\mathrm{P}<0.05)$ for genotype-by-location-by-water stress interaction effects indicating the influence of genotypes, environmental conditions and water stress. The results of high phenolic content also suggested that resistance to late leaf spot and phenolics are highly associated. It was observed that coefficient of variation (CV\%) recorded was less than 50\% indicating the accuracy of the experiments which resulted from controlled conditions in the screen houses.

\subsection{Analysis of variance of Chlorophyll}

Results of analysis of variance of Chlorophyll A, chlorophyll B and total chlorophyll are presented in Table 4

Table 4 Means of sum of squares of chlorophylls of LLS resistant and drought tolerant groundnut genotypes

\begin{tabular}{lllll}
\hline SOV & DF & Chlorophyll A & Chlorophyll B & $\begin{array}{l}\text { Total } \\
\text { Chlorophyll }\end{array}$ \\
\hline Rep & 1 & 1.89 & 1.636 & 7.049 \\
Genotype (G) & 7 & $15.355^{* * *}$ & $4.891^{* * *}$ & $30.231^{* * *}$ \\
Location (L) & 1 & $846.068^{* * *}$ & $344.052^{* * *}$ & $2269.178^{* * *}$ \\
Treatment (T) & 8 & $102.642^{* * *}$ & $80.045^{* * *}$ & $360.879^{* * *}$ \\
GxL & 7 & $26.551^{* * *}$ & $11.776^{* * *}$ & $70.202^{* * *}$ \\
GxT & 44 & $2.445^{* * *}$ & 1.045 & $4.254^{* * *}$ \\
LxT & 8 & $16.953^{* * *}$ & $8.756^{* * *}$ & $48.417^{* * *}$ \\
GxLxT & 44 & $2.653^{* * *}$ & $2.743^{* * *}$ & $6.056^{* * *}$ \\
Residual & 119 & 1.12 & 1.317 & 1.73 \\
Total & 239 & 10.27 & 6.26 & 28.925 \\
\hline CV\% & & 24.45 & 34.49 & 17.19 \\
\hline
\end{tabular}

LLS: Late leaf spot disease, SOV: Source of variance, DF: degree of freedom, ${ }^{* * *}$, Significant at $\mathrm{P}<0.001$ 
Chlorophyll A, chlorophyll B and total chlorophyll showed highly significant differences (P < 0.001) among genotypes and genotype-by-location-by-water stress interaction effects indicating the existence of high chlorophylls as an indication of genotype resistance to late leaf spot disease under water stress across locations. The variation in chlorophylls across sites could be due to the differences in light and other environmental effects [37].

Means of chlorophyll A and chlorophyll B are presented in Table 5. The highest chlorophyll B was recorded under normal water condition (T1) for Abutalata and C11 with values of 11.29 and 10.25 respectively. The lowest chlorophyll B (0.04) was recorded under LLS+GRD+60\% water stress for SGV ER 10003 indicating a decrease in chlorophyll pigments of infected plants with both diseases under $60 \%$ water stress attributed to the consequence of the fungal reduction of the plant leaf area [16].

The highest chlorophyll A recorded at MUARIK were 15.04, 13.48 and 12.38 under normal water condition (T1) by C11, C1 and Abutalata, respectively. These late leaf spot resistant genotypes which showed high chlorophyll A and B indicated that chlorophyll content was most important in groundnut resistance to late leaf spot. Amrik, [38] reported that the increased levels of chlorophyll A, B and total chlorophyll play a vital role in plant defence mechanisms.

The results of total chlorophyll content are presented in Table 6. It ranged between 1.05 and $25.29 \mathrm{mg} / \mathrm{g}$ for C2 at LLS+GRD+60\% water stress at NaCRRI and C11 at $80 \%$ watering at MUARIK. The high total chlorophyll content at MUARIK over NaCRRI could have been due to the available light and other environmental effects like temperature [37]. C11, Abutalata, C1 and SGV ER 10003, showed high total chlorophyll under non-stressed condition with values of 25.29, 23.66, 22.76 and 20.53, respectively at MUARIK. The high total chlorophyll detected under late leaf spot infection with values of 19.16, 16.27 and 16.24 observed for C1, SGV ER 10003 and C11, respectively, indicated the resistance ability of these genotypes and confirmed the role of high total chlorophyll in resistance against late leaf spot disease [26].

Some of the genotypes showed a trend of increasing total chlorophyll under diseases and drought stress such as Abutalata at MUARIK which showed 12.43 under LLS+60\% water stress which was higher than 10.11 and 6.15 under GRD and LLS+GRD indicating that the drought combined with the disease led to increased chlorophyll contents in the plant. These results suggested that the increasing chlorophyll content was due to a drought tolerance mechanism [39].

Means of phenolic contents in the leaves of late leaf spot resistant and susceptible genotypes under the different treatments are presented in Table 7. The highest phenolic content was recorded for late leaf spot resistant genotypes, with genotype Abutalata recording $0.355,0.333$ and 0.322 phenolic content, whiles C1 recorded $0.333,0.303$ and 0.305 at T1, LLS, and T2, respectively. The phenolic content recorded by LLS susceptible genotypes was lower than that of resistant ones even under normal conditions as shown by SGV ER 10004 with high phenolic content at normal conditions (T1) with a value of 0.317; SGV ER 10009 showed 0.313 at T1. These results indicate that phenolic contents play a significant role in plant resistance to late leaf spot [40]. Similarly, Karunakaran and Raj [41] reported that the levels of total phenols was higher in late leaf spot resistant genotypes than the susceptible genotypes.

Imposing drought stress on these tolerant genotypes showed no negative effect on resistance mechanisms as evidenced in T2 which was found not to be associated with low biochemical content compared to LLS and GRD resistant genotypes. This could be due to drought reducing the amount of wet part exposed to diseases as the disease vectors prefer relatively high moisture [16]. Similarly, drought tolerant groundnut lines with high resistance to the aphids have been reported by Deom et al. [42]. 
Mohammed et al. / GSC Biological and Pharmaceutical Sciences 2019, 08(01), 012-027

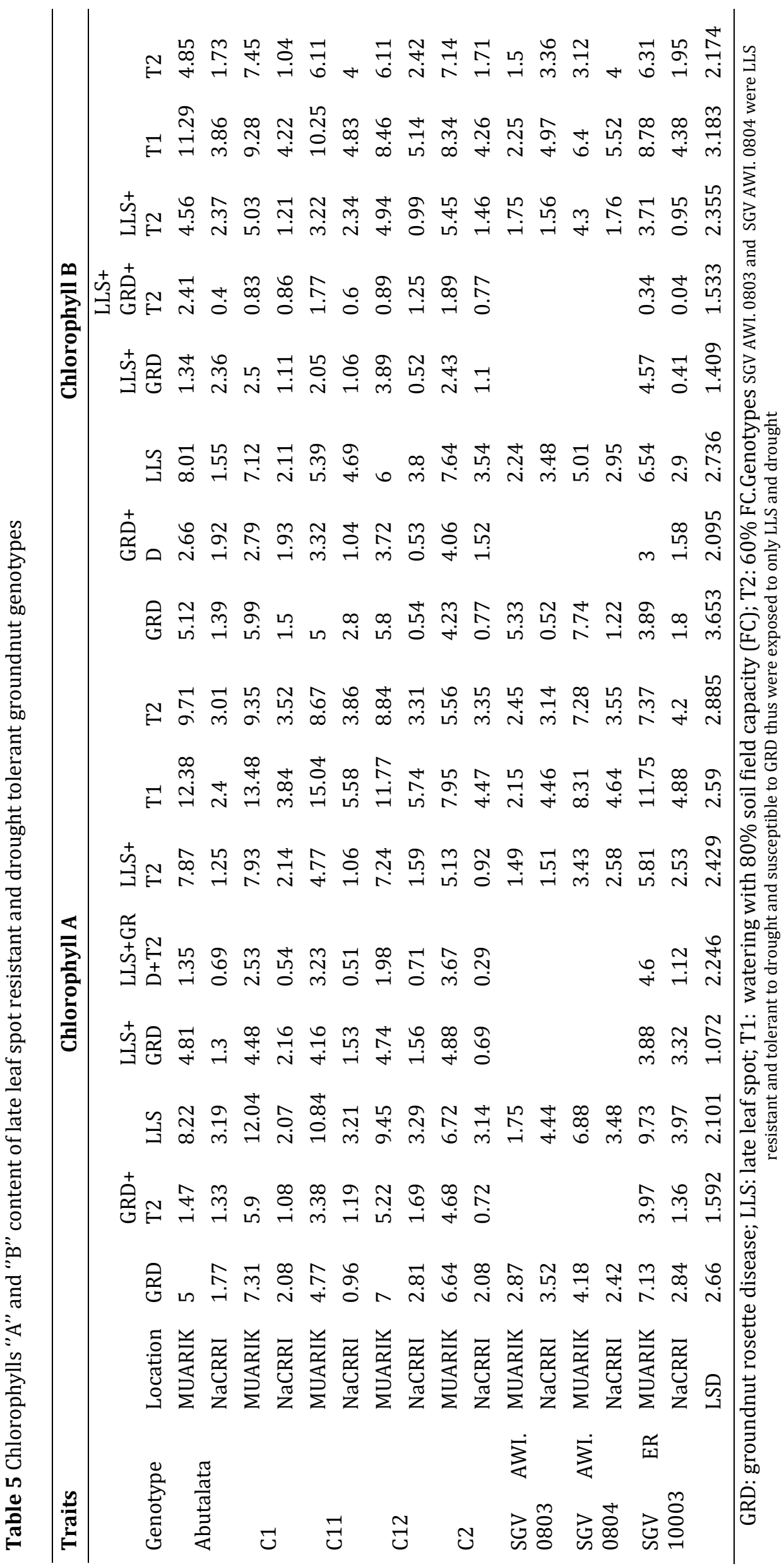


Mohammed et al. / GSC Biological and Pharmaceutical Sciences 2019, 08(01), 012-027

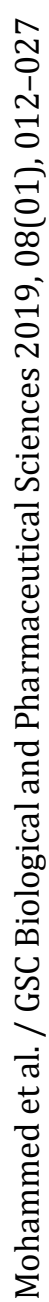

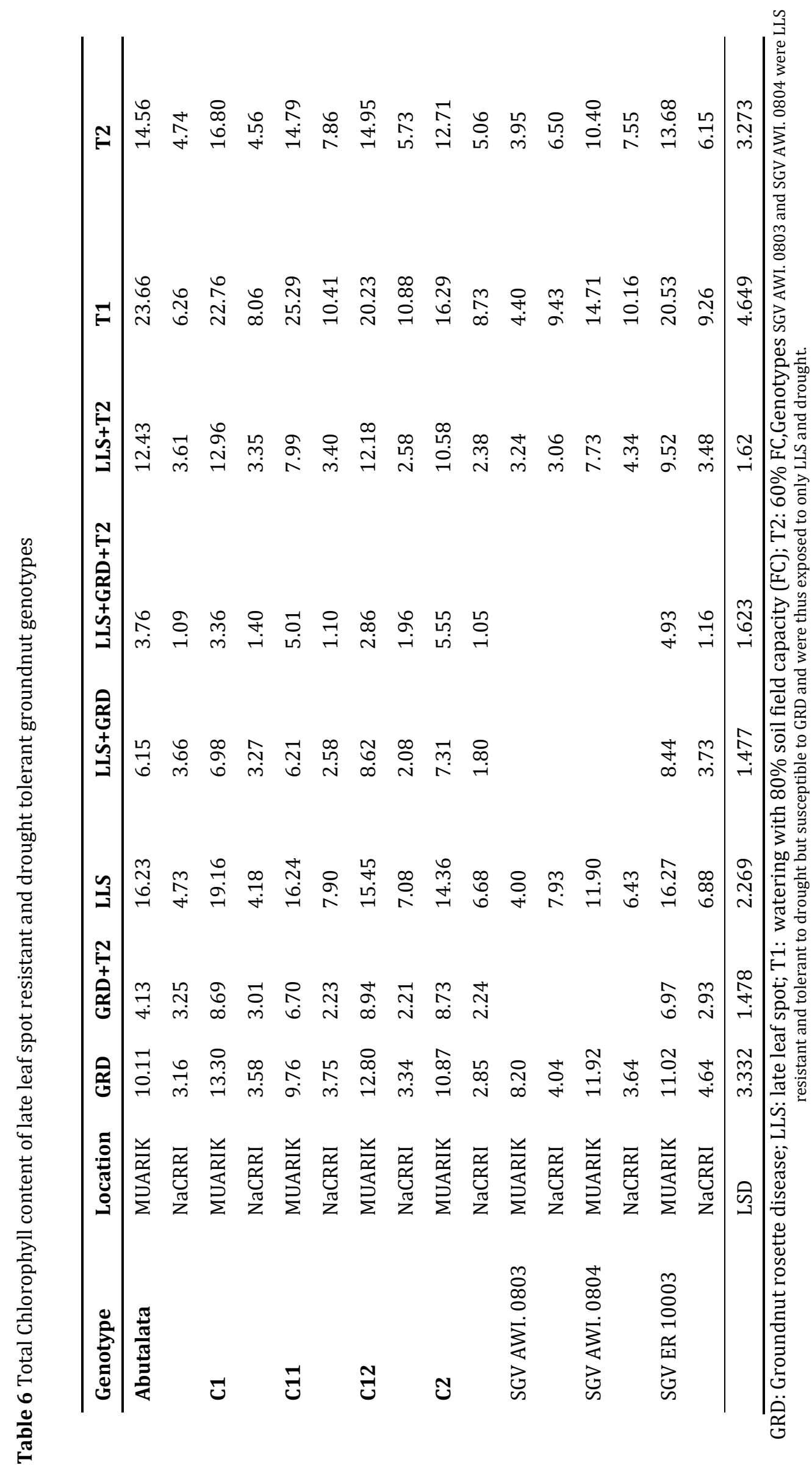




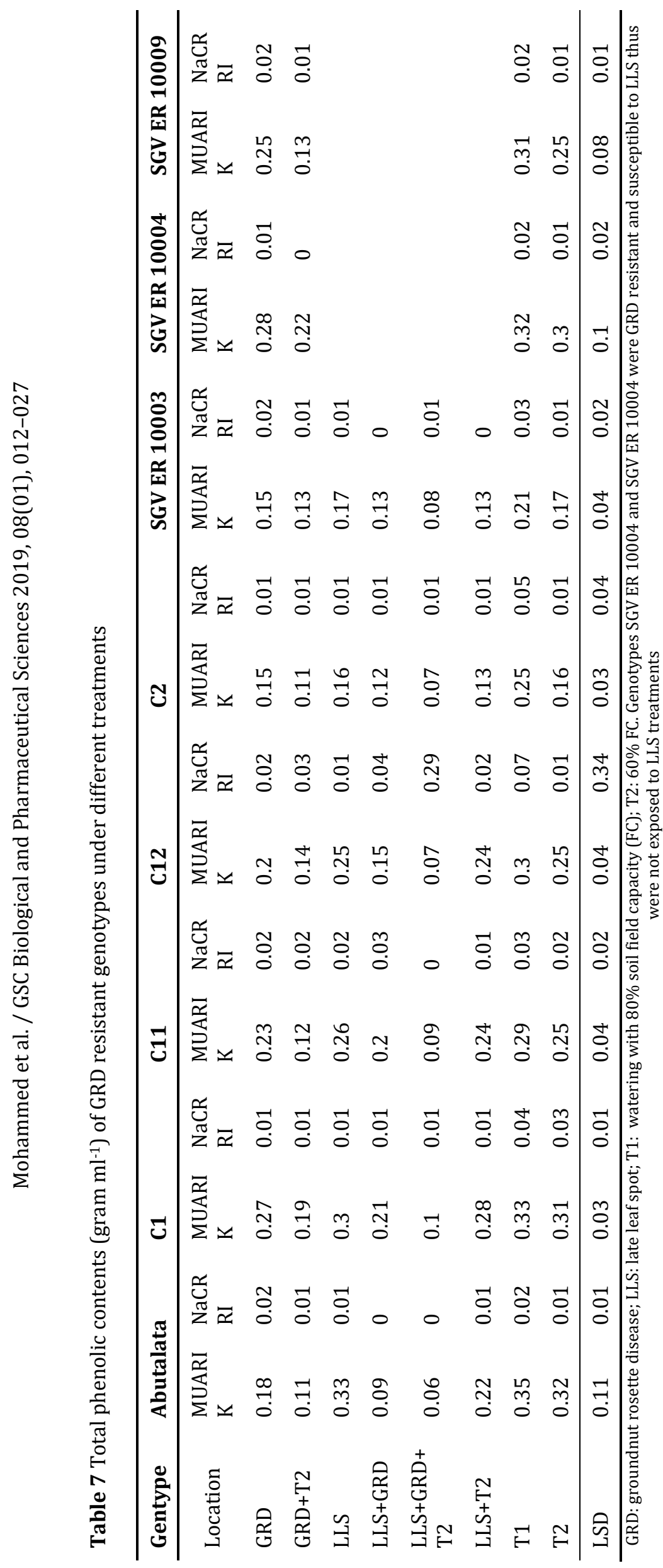




\subsection{Means of tannin contents of rosette disease resistant and susceptible genotypes}

Tannin results of resistant and susceptible genotypes to GRD are presented in Table 8. The tannin results ranged between 0.52 at T1 and 0.01 at LLS + GRD and LLS + GRD + T2. The highest tannin content was recorded by Abutalata which is a GRD resistant genotype. The GRD susceptible genotypes showed low tannin content under single and multiple stress conditions. C12 showed 0.02 at GRD and LLS +GRD +T2 and C11 showed 0.05 at GRD +T2 and LLS + T2.

The high tannin content of GRD resistant genotypes over the susceptible ones indicated that tannins led to decreased nutrient availability for the aphids (GRD vector). This was predicted as the tannins have long been hypothesized to play a role in plant defense [43] as plants with high tannin content had few aphids population [36]. However, subsequent studies showed that tannins may be toxic through their reduction of harmful oxygen radicals and quinines [44]. Clear evidence for the oxidation of tannins and their negative effects on aphids has been presented by Barbehenn et al. [45]. Similarly, Kimmins et al. [12] studied condensed tannin levels and resistance of groundnuts against aphids and found that high condensed tannin existed in resistant genotype and was strongly negative to GRD and its aphid vector.

High tannin content recorded by some genotypes under drought stress such as C1 recording 0.191 at T2 compared to 0.166 at T1 and SGV ER 10004 recording 0.294 at T2 compared to 0.264 at T1 indicated the drought tolerance of these genotypes was due to the tannins present which act as antioxidants under stress conditions [46] as well as acting as a mechanism of resistance to GRD and its aphid vector [36]. 
Mohammed et al. / GSC Biological and Pharmaceutical Sciences 2019, 08(01), 012-027

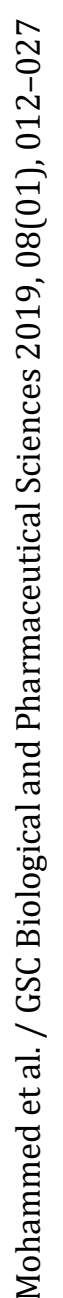

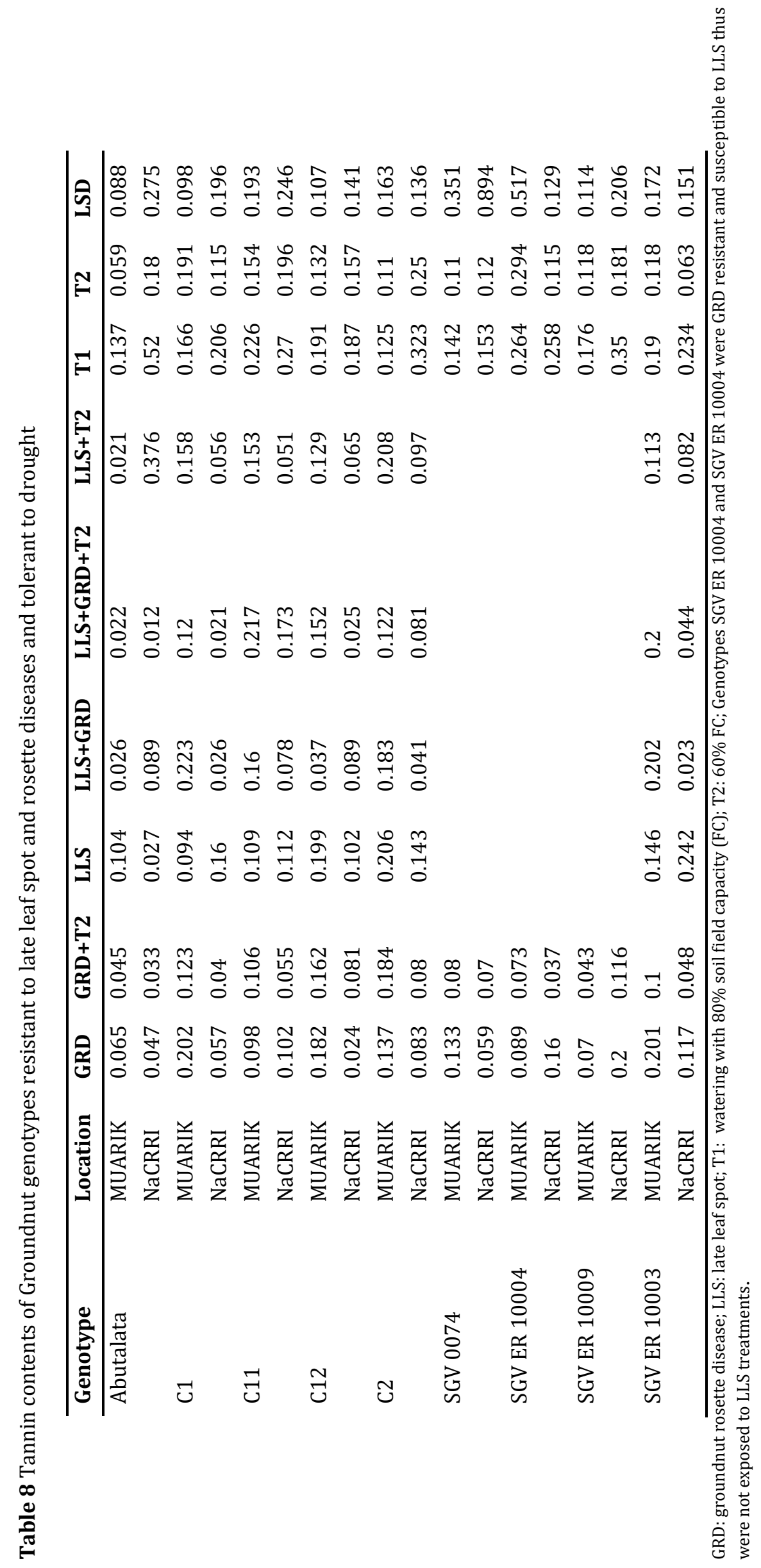




\subsection{Associations of mechanism of traits of late leaf spot and rosette diseases resistance in drought tolerant groundnut genotypes}

The results of analysis of correlation of biochemicals and aphid counts are presented in Table 9. The tannin content $(\mathrm{g} / \mathrm{m})$ showed negative weak correlation with chlorophyll A ( $\mathrm{r}=-0.002)$, chlorophyll B $(\mathrm{r}=-0.064)$ and total chlorophyll $(\mathrm{r}=-0.034)$ indicating that chlorophyll contents slightly reduced with an increase in tannins.

Tannin showed weak negative correlation with Aphid number per plant at the second, third and fourth counts with values of $-0.038,-0.130$ and -0.082 , respectively, indicating that the tannin slightly decreased the growth rate of the insect [47].

Table 9 Correlation of plant mechanisms for late leaf spot and rosette diseases resistance in groundnut genotypes

\begin{tabular}{|c|c|c|c|c|c|c|c|c|c|}
\hline Traits & Tannin & $\begin{array}{l}\text { Tot } \\
\text { phn }\end{array}$ & Chl A & Chl B & Tot Chl & $\begin{array}{l}\text { Aphid } \\
\text { count } 1\end{array}$ & $\begin{array}{l}\text { Aphid } \\
\text { count } 2\end{array}$ & $\begin{array}{l}\text { Aphid } \\
\text { count } 3\end{array}$ & $\begin{array}{l}\text { Aphid } \\
\text { count } 4\end{array}$ \\
\hline Tannin & - & & & & & & & & \\
\hline Tot phn & 0.037 & - & & & & & & & \\
\hline Chl A & -0.002 & $\begin{array}{l}0.5813 \\
* * *\end{array}$ & - & & & & & & \\
\hline Chl B & -0.064 & $\begin{array}{l}0.575^{* *} \\
*\end{array}$ & $\begin{array}{l}0.5577^{*} \\
* *\end{array}$ & - & & & & & \\
\hline Tot Chl & -0.034 & $\begin{array}{l}0.6545 \\
* * *\end{array}$ & $\begin{array}{l}0.9063^{*} \\
* *\end{array}$ & $\begin{array}{l}0.856^{* *} \\
*\end{array}$ & - & & & & \\
\hline $\begin{array}{l}\text { Aphid } \\
\text { count } 1\end{array}$ & 0.051 & $\begin{array}{l}0.3094 \\
* *\end{array}$ & $\begin{array}{l}0.4029 * \\
* *\end{array}$ & $\begin{array}{l}0.315^{* *} \\
*\end{array}$ & $\begin{array}{l}0.411^{* *} \\
*\end{array}$ & - & & & \\
\hline $\begin{array}{l}\text { Aphid } \\
\text { count } 2\end{array}$ & -0.038 & 0.167 & $\begin{array}{l}0.3247^{*} \\
* *\end{array}$ & $\begin{array}{l}0.351^{* *} \\
*\end{array}$ & $\begin{array}{l}0.381^{* *} \\
*\end{array}$ & 0.13 & - & & \\
\hline $\begin{array}{l}\text { Aphid } \\
\text { count } 3\end{array}$ & -0.13 & $\begin{array}{l}- \\
0.409 * * \\
*\end{array}$ & $-0.250^{* *}$ & $-0.236^{*}$ & $\begin{array}{l}- \\
0.276^{* *}\end{array}$ & $-0.237^{* *}$ & $0.305^{* *}$ & - & \\
\hline $\begin{array}{l}\text { Aphid } \\
\text { count } 4\end{array}$ & -0.082 & $\begin{array}{l}- \\
0.438^{* *}\end{array}$ & $\begin{array}{l}- \\
0.379 * * \\
*\end{array}$ & $\begin{array}{l}- \\
0.330^{* *}\end{array}$ & $\begin{array}{l}- \\
0.404^{* *}\end{array}$ & $-0.233^{*}$ & $0.301^{* *}$ & $0.768^{* * *}$ & - \\
\hline
\end{tabular}

Kimmins et al. [12] studied groundnuts resistance to aphids and its condensed tannin levels and found a strong negative correlation between the concentrations of tannin in the leaf of groundnut genotypes and the aphid counts.

Total phenolic content showed highly significant $(\mathrm{P}<.001)$ negative correlation with third and fourth aphid counts indicating that accumulation of phenolics constituted a strong protection against aphids [48].

Total phenolic content showed highly significant $(\mathrm{P}<.001)$ positive correlation with Chlorophyll $\mathrm{A}$, Chlorophyll B and total Chlorophyll content indicating the indirect contribution of phenolics to late leaf spot resistance as chlorophyll is positively related to resistance to LLS [21] and therefore, phenolics enable the plant leaves to maintain high chlorophyll content which therefore, decreases the infection of late leaf spot.

The negative correlation between the content of phenols, tannins and chlorophylls and aphid population indicated that an increase in the content of these metabolites contributed to the bioprotection of host plants against the infection of LLS and GRD.

\section{Conclusion}

High chlorophylls and tannins in the drought tolerant genotypes were related to resistance to late leaf spot and rosette diseases. The variations observed in chlorophylls, phenols and tannin activity among the resistant genotypes indicated that these metabolites increase resistance to LLS and GRD in groundnut through their negative effect to the vectors. The negative association of plant biochemicals with the aphid population and positive association of 
chlorophylls and phenolic contents indicated that an increase in the content of these plant substances contribute to the protection of host plants.

\section{Compliance with ethical standards}

\section{Acknowledgments}

The Share Intra ACP provided financial support through a scholarship and Carnegie Cooperation of New York, through the Regional Universities Forum for Capacity Building in Agriculture (RUFORUM) provided a capacity building competitive grant to support the research. The genetic materials, field, laboratory facilities and technical assistance were provided by National Semi-Arid Resources Research Institute (NaSARRI) and National Crop Resources Research Institute (NaCRRI).

\section{Disclosure of conflict of interest}

No conflict of interest exist.

\section{References}

[1] Wang ML, Pinnow DL and Pittman RN. (2007). Preliminary screening of germplasm in the US collection for TSWV resistance and high flavonoid content. Plant Pathology Journal.

[2] Asekenye C. (2012). An analysis of productivity gaps among smallholder groundnut farmers in Uganda and Kenya. University of Connecticut.

[3] Kassie M, B. Shiferaw and G. Muricho. (2011). Agricultural technology, crop income and poverty alleviation in Uganda. World Development, 39, 1784-1795.

[4] Harris D and Azam-Ali SN. (1993). Implication of day length sensitivity in bambara groundnut (Vigna subtarranea) production in Botswana. J. Agric. Sci., 120, 75-78.

[5] Doku EV. (1996). Problems and prospects for the improvement of bambara groundnut. Proceedings of the International Bambara Groundnut Symposium, July 23-25, University of Nottingham, UK, 19-27.

[6] Ganesan S. and R. Sekar. (2004). Biocontrol mechanism of groundnut (Arachis hypogaea L.) diseasesTrichoderma system. In: Biotechnological Applications in Environment and Agriculture, Eds: G.R. Pathade and P.K. Goel, ABD Pub. Jaipur, India, 312-327.

[7] Smith BW. (1994). Foliar Diseases, 55-57. In: Compendium of Peanut Disease. American Phyto-pathological Society, 77.

[8] Okello DK, Akello LB, Tukamuhabwa P, Odong TL, Ochwo-Ssemakula M, Andriko J and Deom CM. (2014). Groundnut rosette disease symptoms types distribution and Management of the disease in Uganda. African Journal of Plant Sciences, 8(3), 153-163.

[9] Ambang Z, B. Ndongo, G. Essono, JP Ngoh, P. Kosma, GM Chewachong and A. Asanga. (2011). Control of leaf spot disease caused by Cercospora sp on groundnut (Arachis hypogaea) using methanolic extracts of yellow oleander (Thevetia peruviana) seeds. Aust. J. Crop Sci., 5, 227-232.

[10] Umma M, As K. and Wa A. (2014). An overview of eight major Groundnut Diseases in Nigeria and their Management. Journal of Plant Sciences, 2(12), 51-59.

[11] Okoko ENK, DJ Rees, JK Kwach, and P. Ochieng. (1999). Participatory evaluation of groundnut production, Southwest Kenya. In Towards increased use of demand driven technology, ed. J.A Sutherland, 305-307.

[12] Kimmins FM, Padgham DE, Harborne JB and Rao DVR. (1992). Condensed tannin levels and resistance of groundnuts (Arachis hypogaea) against aphis cracczvora. Phytochemistry, 31(11), 3795-3800.

[13] Ntare BR, Olorunju PE and Hildebrand GL. (2002). Progress in breeding early maturing peanut cultivars with resistance to groundnut rosette diseases in West Africa. Peanut Sci. 29, 17-23.

[14] Huang B, and Fry JD. (1998). Root anatomical, physiological, and morphological responses to drought stress for tall fescue cultivars. Crop Science 38, 1017-1022. 
[15] Clarke JM, and MC Caig TN. (1982). Evaluation of techniques for screening for drought resistance in wheat. Crop Science 22, 503-506.

[16] Agrios GN. (2005). Plant pathology. 5th ed. Elsevier Academic Press. Burlington, MA, USA.

[17] Rathnakumar AL, Chuni lal, VK Jain and JB Mishra. (2004). Biochemical changes associated with rust (Puccinia arachidis Speg.) resistance in groundnut. In National Symposium Enhancing productivity of Groundnut for sustaining food and Nutritional security. October 11-13, 226-227.

[18] Hiramath PC and RD Savanpur. (1990). Biochemical changes in cotton leaves in response to Alternaria macrospora infection. Current Res. Univ. Agric.Sci., 19, 142-143.

[19] NARO. (2005). The National Crops Resources Research Institute (NaCRRI).

[20] Hemantkumar N. (2005). Characterization of groundnut (Arachis hypogaea L.) germplasm in relation to major foliar pests and diseases. Saurashtra University.

[21] Ibrahim YJ. (2010). Screening of groundnuts (Arachis hypogaea L.) for resistance to early and late leaf spots. MSc. Thesis, Kwame Nkrumah University of Science and Technology, Kumasi, Ghana.

[22] Kayondo SI, PR Rubaihayo, BR Ntare1, PT Gibson, R. Edema, A. Ozimati and Okello DK. (2014). Genetics of resistance to Groundnut rosette disease. African Crop Science Journal. 22(1), 21 - 29.

[23] Shinde BM, and Laware SL. (2014). Screening of groundnut (Arachis hypogaea L.) varieties for drought tolerance through physiological indices. Environmental Research and Development, 9(2), 375-381.

[24] Mwale SE, Ssemakula MO, Sadik K, Alladassi B, Gibson P, Singini W and Edema R. (2017). Estimates of combining ability and heritability in cowpea genotypes under drought stress and non- stress conditions in Uganda. Journal of Plant Breeding and Crop Science, 9(2), 10-18.

[25] Terzi RAT and Kadioglu ASIMK. (2006). Drought s tress tolerance and the antioxidant enzyme system. biologica cracoviensia, 48(2), 89-96.

[26] Jyosthna MK, Reddy NPE, Chalam TV and Reddy GL K. (2004). Morphological and biochemical characterization of Phaeoisariopsis personata resistant and susceptible cultivars of groundnut (Arachis hypogaea). Plant Pathology, 13(4), 243-250.

[27] Sadasivam S. and Manickam A. (1996). Biochemical methods. New Age International, P, Limited Publishers, New Delhi, 256.

[28] Mushrif SK. (2010). Epidemiology and management of tikka disease of groundnut caused by Cercospora arachidicola Hori and Cercosporidium personatum (Berk. and Curt.) Deighton. University of Agricultural Sciences, Bangalore.

[29] Mwila N, Rubaihayo PR, Kyamanywa, S, Odong TL, Nuwamanya E, Mwala M and Badji A. (2017). Biochemical factors associated with cassava resistance to whitefly infestation. African Crop Science Journal, 25(3), 365-385.

[30] Kähkönen MP, Hopia AI, Vuorela HJ, Rauha JP, Pihlaja K, Kujala TS and Heinonen M. (1999). Antioxidant activity of plant extracts containing phenolic compounds, Journal of Agricultural and Food Chemistry, 47, 3954-3962.

[31] Gorbet DW, Kucharek TA, Shokes FM and Brenneman TB. (2004). Field evaluations of peanut germplasm for resistance to stem rot caused by Sclerotium rolfsii. Peanut Sci. 31, 91-95.

[32] Alhassan U. (2013). Genetic analysis of resistance to rosette disease of groundnut (Arachis hypogaea l.) PhD theses. University of Ghana.

[33] Berchoux DE, CD. (1960). La rosette de l.arachide en Haute-Volta. Comportement de lignées résistantes. Oléagineux 15, 229-223.

[34] Sulistyo A. and Inayati A. (2016). Mechanisms of antixenosis, antibiosis, and tolerance of fourteen soybean genotypes in response to whiteflies (Bemisia tabaci). Biodiversitas 17(2), 447-453.

[35] Taggar GK, Gill RS, Gupta AK and Singh S. (2014). Induced changes in the antioxidative compounds of Vigna mungo genotypes due to infestation by Bemisia tabaci (Gennadius). Journal Environmental Biology 35(6), 1037-45.

[36] Alpha RW. (2013). Effects of poplar phenolics on the fitness and behaviour of Chaitophorus aphids. University of Victoria. 
[37] Pavlovic D, Nikolic B, Durovic S, Waisi H and Anđelkovic A. (2014). Chlorophyll as a measure of plant health: Agroecological aspects. Pestic Phytomed, 29(1), 21-34.

[38] Amrik SS. (2012). Development of integrated disease management package and transgenic technology for the control of powdery mildew (Leveillula taurica) in capsicum (Capsicum annuum L.). Indian Institute of Horticultural Research.

[39] Schelmmer MR, francis DD, Shanahan JF and Schepers JS. (2005). Remotely measuring chlorophyll content in corn leaves with differing nitrogen levels and relative water content. Agron. J, 97, 106-112.

[40] Mayee CD. (1995). Current status and future approaches for management of groundnut disease in India. Indian Phytopath, 48, 389-401.

[41] Karunakaran P. and Raj JS. (1980). Role of ascorbic acid on "tikka" disease of peanut. Agric. Res. Journal of Karala 18, 116-117.

[42] Deom CM, T Kapewa, CM, Busolo-Bulafu RA, Naidu AJ, Chiyembekeza FM, Kimmins P, Subrahmanyam and PJA, van der Merwe. (2006). "Registration of ICG 299 peanut germplasm line." Crop Science Journal, 46, 481.

[43] Feeny P. (1970). Seasonal changes in oak leaf tannins and nutrients as a cause of spring feeding by winter moth caterpillars. Ecology 51:565-581.

[44] Appel H. M. (1993). Phenolics in ecological interactions: The importance of oxidation. Journal of Chemical Ecology 190, 1521-1552.

[45] Barbehenn RV, Jaros A, Lee G, Mozola C, Weir Q and Salminen J. (2009). Tree resistance to Lymantria dispar caterpillars: Importance and limitation of foliar tannin composition. Oecologia 159, 777-788.

[46] MabhaudhI T, and Modi AT. (2013). Growth, phenological and yield responses of a bambara groundnut (Vigna subterranea L. Verdc) landrace to imposed water stress: I. Field conditions. S.Afr. J. Plant Soil 30, 2.

[47] Waterman PG. (1988). Plant Flauonoids in Biology and Medicine, II. (Cody, V., Middleton, E. Jnr., Harborne, J. B and Beretz A, eds), 77. Alan R. Lisa New York.

[48] Barbehenn RV and Constabel CP. (2011). Tannins in plant-herbivore interactions. Phytochemistry 72, 15511565.

\section{How to cite this article}

Mohammed KE, Ephraim N, Emmanuel A, Wembabazi E, Mwila N, Siddig E I and Rubaihayo PR. (2019). Resistance mechanisms of late leaf spot and rosette diseases in drought tolerant groundnut genotypes. GSC Biological and Pharmaceutical Sciences, 8(1), 12-27. 